\title{
Prospective surveillance study of severe hyperbilirubinaemia in the newborn in the UK and Ireland
}

\author{
Donal Manning, Peter Todd, Melanie Maxwell, Mary Jane Platt
}

Arch Dis Child Fetal Neonatal Ed 2007;92:342-346. doi: 10.1136/adc.2006.105361

See end of article for authors' affiliations

Correspondence to:

Donal Manning, Department of Paediatrics, Arrowe Park Hospital, Wirral, Merseyside CH49 5PE, UK; donal. manning@whnt.nhs.uk

Accepted 23 October 2006 Published Online First 27 October 2007

\begin{abstract}
Objectives: To determine the incidence of severe hyperbilirubinaemia in the newborn, and to identify associated clinical and demographic variables, and short-term outcomes.

Design: Prospective, population-based study.

Setting: UK and Republic of Ireland, between 1 May 2003 and 31 May 2005.

Participants: Infants in the first month of life with severe hyperbilirubinaemia (maximum unconjugated serum bilirubin $\geqslant 510 \mu \mathrm{mol} / \mathrm{I})$.

Results: 108 infants met the case definition, 106 from the UK and 2 from the Republic of Ireland. The UK incidence of severe hyperbilirubinaemia was 7.1/100 000 live births $(95 \% \mathrm{Cl} 5.8$ to 8.6$)$. Only 20 cases presented in hospital; 88 were admitted with severe jaundice. $64(60.4 \%)$ cases were male, and $56(51.8 \%)$ were of ethnic minority origin. $87(80.5 \%)$ cases were exclusively breast fed. Co-morbidity included haemolysis, dehydration, infection and bruising. 14 infants showed evidence of bilirubin encephalopathy, of whom 3 died. The UK incidence of bilirubin encephalopathy was $0.9 / 100000$ live births $(95 \% \mathrm{Cl} 0.46$ to 1.5).

Conclusions: This is the first large, prospective, population-based study of the incidence of severe hyperbilirubinaemia in the newborn. The clinical and demographic associations, and short-term outcomes identified, are the same as those reported recently in North America and Europe.
\end{abstract}

1 $\mathrm{n}$ the past 15 years, severe hyperbilirubinaemia has been reported with increasing frequency in term and near-term infants in North America and Europe. ${ }^{1-9}$ Severe hyperbilirubinaemia can cause encephalopathy with important sequelae among surviving infants, including athetoid cerebral palsy, sensorineural hearing loss, paralysis of upward gaze and dental enamel dysplasia. ${ }^{15} 6$ 8-10 A pilot kernicterus register established in Philadelphia in 1992 had accumulated information on 145 affected infants by $2002 .{ }^{6}$ In Denmark, eight cases of neonatal bilirubin encephalopathy were reported between 1994 and 2002, no cases having been reported in the preceding 20 years. ${ }^{59}$ Little is known of similar trends in the UK and Ireland, and there have been no recent published reports of bilirubin encephalopathy in mature infants.

The primary objective of this study was to determine the incidence of severe hyperbilirubinaemia in the UK and Ireland. Secondary objectives were to document clinical and demographic variables associated with severe jaundice, and the associated consequences, including the need for exchange transfusion, bilirubin encephalopathy and death.

\section{METHOD}

The study was included in the British Paediatric Surveillance Unit reporting scheme between June 2003 and June 2005 (surveying for cases seen between May 2003 and May 2005). Members of the Royal College of Paediatrics and Child Health receive a mailing every month asking whether they have encountered any of a selected number of rare diseases in the preceding month. Responders are sent an anonymised questionnaire requesting information to determine whether the reported case meets the case definition, and to collect associated clinical and demographic information.

The case definition for severe hyperbilirubinaemia was "an infant with an unconjugated serum bilirubin concentration of $\geqslant 510 \mu \mathrm{mol} / \mathrm{l}$ in the first month of life". Information requested from paediatricians reporting cases included: the infant's sex, ethnic origin (using the categories used by the Office for National Statistics), birth weight, gestation, mode of feeding and age at discharge from the maternity unit; the maximum unconjugated serum bilirubin concentration and the age at which this was identified; symptoms consistent with encephalopathy (impaired consciousness, hypotonia, opisthotonus and seizures); and diseases associated with jaundice. We defined probable $\mathrm{ABO}$ incompatibility as appropriate maternal-infant blood group permutations with positive Coombs' test, and possible $\mathrm{ABO}$ incompatibility as appropriate blood groups with negative Coombs' test. Otherwise we relied on the reporting paediatricians to specify associated diagnoses. Other consequences of severe hyperbilirubinaemia were recorded, including treatment by exchange transfusion, findings on MRI brain scans and death.

The denominator for calculating the incidence of severe hyperbilirubinaemia was routinely collected live births during the study period, obtained from the Office for National Statistics for England and Wales, the General Register Office for Scotland and the Northern Ireland Statistics and Research Agency. Live birth data by month were not available for the Republic of Ireland, so cases reported from there were not included in the incidence calculations. Republic of Ireland cases, however, were included in analysis of clinical and demographic variables associated with severe hyperbilirubinaemia.

We analysed the data using Stata (version 8). Where indicated, exact $95 \%$ confidence intervals were calculated.

The London multicentre research ethics committee approved the study.

\section{RESULTS}

Of 177 reports received, 108 met the case definition. There were 38 reporting errors and 25 duplicate reports, and no information was obtained in six cases. All except two cases were from the UK where, over the same time period, there were 1500052 


\begin{tabular}{lc} 
Table 1 Distribution of demographic and \\
perinatal variables. Values are numbers (\%) unless \\
otherwise stated \\
\hline Variable & No. (\%) \\
\hline Male sex & $64(60.4)$ \\
Ethnic group & $52(48.1)$ \\
White & $18(16.7)$ \\
Asian/Asian British & $11(10.1)$ \\
Black/black British & $11(10.1)$ \\
Mixed & $16(14.8)$ \\
Other & $3170(480)$ \\
Birth weight (g), mean (SD) & $38.2(1.7)$ \\
Gestational age (weeks), mean (SD) & \\
Mode of delivery & $63(58.3)$ \\
Normal vaginal & $25(23.1)$ \\
Instrumental vaginal & $20(18.5)$ \\
Caesarean section & $87(80.5)$ \\
Feeding method & $13(12.0)$ \\
Breast & $6(5.5)$ \\
Artificial & \\
Mixed & 49 \\
Associated problems & 6 \\
Suspected haemolysis & 16 \\
Rhesus incompatibility & 17 \\
Probable ABO incompatibility & 5 \\
Possible ABO incompatibility & \\
Glucose 6-phosphate dehydrogenase & \\
deficiency & 3 \\
Hereditary spherocytosis & 29 \\
Other causes of haemolysis & 30 \\
Dehydration & 7 \\
Bruising & \\
Sepsis & \\
Miscellaneous & \\
No associated pathology & \\
& \\
&
\end{tabular}

live births, giving an incidence of 7.1/100 000 live births (95\% CI 5.8 to 8.6/100 000 live births). Thirteen of the UK infants had symptoms or a clinical course consistent with bilirubin encephalopathy, an incidence of 0.9/100 000 live births (95\% CI 0.46 to 1.5 ). One further case of bilirubin encephalopathy was reported from the Republic of Ireland.

Among the cases of hyperbilirubinaemia 64 were male infants $(60.4 \%)$. Fewer than half the cases were described ethnically as "white" (table 1). The mean gestational age at delivery was 38.2 weeks (range 35-42), and the mean birth weight was $3190 \mathrm{~g}$ (range 1.79-4.3). Eighty-eight (77.7\%) cases were born vaginally, $25(29 \%)$ of whom had instrumental deliveries. Breast feeding was the commonest mode of feeding (table 1). There was no association between severe hyperbilirubinaemia and month of birth.

The mean peak serum bilirubin concentration was $580 \mu \mathrm{mol} / \mathrm{l}$ (range 510-802), and the mean age at peak serum bilirubin concentration was 4.3 days (range 1-9). At diagnosis, over a quarter of infants were dehydrated, having lost more than $10 \%$ of their birth weight. Twenty-eight (93\%) of these infants had been exclusively breast fed. In nearly half of all cases, a haemolytic disease was suspected or confirmed (table 1). Other associated problems included sepsis and marked bruising in association with cephalhaematoma. Of the 29 cases with no associated problems, 26 (90\%) had been exclusively breast fed.

In all, 48 infants were treated by exchange transfusion, seven of whom received more than one transfusion; 59 infants did not receive an exchange transfusion, and in one case no record was available. The median peak serum bilirubin was significantly greater in infants who were treated by exchange transfusion than in those who were not $(586 \mu \mathrm{mol} / \mathrm{l} v 544 \mu \mathrm{mol} / \mathrm{l}$, respectively, $\mathrm{p}<0.001)$. Compared with infants who were not transfused, infants receiving exchange transfusion were more likely to have had neurological symptoms (9 (15\%) v 15 (31\%), $\mathrm{p}<0.05$, respectively) and to have had associated haemolysis $(19(32 \%) \vee 30(62 \%), \mathrm{p}<0.01$, respectively), and were less likely to have had no associated diagnosis (20 (34\%) v8 (16\%), $\mathrm{p}<0.05$, respectively).

In all, 104 cases were delivered in hospital, although only 20 cases presented in hospital. The remaining infants were admitted from home, 84 being readmitted and 4 following home birth. The mean age at initial discharge for those infants readmitted with hyperbilirubinaemia was day 2 (range day 1 to day 5). We found no difference in the peak serum bilirubin concentration of those cases identified in hospital and those admitted from home, although the latter group was older at diagnosis (mean age 2.8 days $v 5.0$ days, respectively, $\mathrm{p}<0.001$ ). Associated haemolysis was significantly more commonly identified in infants diagnosed before discharge (16 (80\%) v $33(38 \%), p<0.001)$. Twelve $(60 \%)$ of infants diagnosed before discharge were treated with an exchange transfusion compared with $36(41 \%)$ of infants presenting from home $(\mathrm{p}=0.08)$.

Table 2 summarises the clinical, demographic, biochemical and outcome findings for infants with bilirubin encephalopathy. Two infants presented while still in hospital, nine were readmitted, and three had been born at home. All three infants with infection died. Postmortem examination was conducted in two cases, and both showed kernicterus. Only one infant with encephalopathy had no identified associated pathology. This infant had been breast fed. Four infants with bilirubin encephalopathy did not receive exchange transfusion-one with overwhelming infection, two with dehydration and one with no associated diagnosis. Four of the surviving infants at 12-month follow-up had typical sequelae, including sensorineural hearing impairment and athetoid cerebral palsy. Three of these infants underwent brain MRI, which showed increased signal in the globus pallidus on $\mathrm{T} 2$-weighted imaging, as described previously in bilirubin encephalopathy. ${ }^{11}$ Three survivors were reported to have normal development at one year, two had neurodevelopmental problems felt to be unrelated to bilirubin encephalopathy and two were lost to follow-up.

Compared with jaundiced infants without encephalopathy, the infants with features suggesting encephalopathy were more likely to be boys (12 (85\%), p =0.037); more likely to be black/ British black (6 (43\%), p <0.001); had significantly higher peak serum bilirubin concentrations (mean $627 \mu \mathrm{mol} / \mathrm{l} v 573 \mu \mathrm{mol} / \mathrm{l}$ in jaundiced infants without encephalopathy, $\mathrm{p}=0.037$ ); were more likely to have a coexistent infection (3 $(21 \%), p=0.007)$; and were significantly more likely to be treated with an exchange transfusion (10 (66\%) v $38(40 \%)$ jaundiced infants without encephalopathy, $p=0.046)$. A multiple logistic regression model demonstrated that ethnic group (black) and glucose 6-phosphate dehydrogenase deficiency independently increased the risk of encephalopathy in infants with hyperbilirubinaemia (table 3).

\section{DISCUSSION}

Between May 2003 and May 2005, the incidence of severe neonatal hyperbilirubinaemia in the UK was $0.07 / 1000$ live births, and the incidence of bilirubin encephalopathy was about 1/100 000 live births. Associations with both severe hyperbilirubinaemia and bilirubin encephalopathy included male sex, ethnic minority origin, breast feeding and comorbidity, including dehydration, marked bruising, haemolytic diseases and infection. Most infants were admitted to hospital for management of jaundice after earlier discharge or a home birth.

Although severe jaundice and bilirubin encephalopathy have been extensively reported in North America in the past 15 
Table 2 Clinical, demographic, biochemical and outcome data for infants with bilirubin encephalopathy

\begin{tabular}{|c|c|c|c|c|c|c|c|c|c|c|}
\hline $\begin{array}{l}\text { Case } \\
\text { no. }\end{array}$ & Sex & $\begin{array}{l}\text { Ethnic } \\
\text { origin }\end{array}$ & $\begin{array}{l}\text { Gestation } \\
\text { (weeks) }\end{array}$ & $\begin{array}{l}\text { Birth } \\
\text { weight } \\
\text { (kg) }\end{array}$ & $\begin{array}{l}\text { Mode of } \\
\text { feeding }\end{array}$ & Clinical features & $\begin{array}{l}\text { Maximum } \\
\text { SBR } \\
(\mu \mathrm{mol} / \mathrm{l})\end{array}$ & $\begin{array}{l}\text { Age at } \\
\text { maximum } \\
\text { SBR (days) }\end{array}$ & Associated pathology & $\begin{array}{l}\text { Outcome at } \\
12 \text { months }\end{array}$ \\
\hline 1 & Male & Black & 41 & 3.34 & Artificial & $\begin{array}{l}\downarrow \text { LOC, } \downarrow \text { tone, } \\
\text { opisthotonus, } \\
\text { seizures }\end{array}$ & 709 & 3 & Klebsiella septicaemia & Died \\
\hline 2 & Male & White & 37 & 2.94 & Breast & $\begin{array}{l}\downarrow \text { LOC, } \downarrow \text { tone, } \\
\text { opisthotonus, } \\
\text { seizures }\end{array}$ & 613 & 8 & Unspecified haemolysis & Hearing loss \\
\hline 3 & Male & Black & 36 & 2.35 & Breast & $\downarrow$ LOC, $\downarrow$ tone & 649 & 4 & $\begin{array}{l}\text { Omphalitis, possible } \\
A B O \text { incompatibility }\end{array}$ & Died \\
\hline 4 & Male & Asian & 36 & 1.79 & Artificial & $\begin{array}{l}\downarrow \text { LOC, } \downarrow \text { tone, } \\
\text { opisthotonus, } \\
\text { seizures }\end{array}$ & 663 & 8 & G6PD deficiency & $\begin{array}{l}\text { Athetosis, severe } \\
\text { hearing loss }\end{array}$ \\
\hline 5 & Male & $\begin{array}{l}\text { South } \\
\text { Asian }\end{array}$ & 39 & 2.83 & Breast & $\begin{array}{l}\downarrow L O C, \downarrow \text { tone, } \\
\text { opisthotonus }\end{array}$ & 563 & 3 & $\begin{array}{l}\text { Dehydration, possible } \\
A B O \text { incompatibility }\end{array}$ & Normal \\
\hline 6 & Female & $\begin{array}{l}\text { Middle } \\
\text { Eastern }\end{array}$ & 40 & 3.24 & Breast & $\downarrow$ LOC, seizures & 802 & 3 & G6PD deficiency & Normal \\
\hline 7 & Male & White & 36 & 3.0 & Artificial & $\downarrow$ tone, seizures & 561 & 4 & Cephalhaematoma & $\begin{array}{l}\text { Incidental } \\
\text { hemiparesis }\end{array}$ \\
\hline 8 & Male & White & 39 & 4.01 & Unknown & $\begin{array}{l}\text { Opisthotonus, } \\
\text { seizures }\end{array}$ & 587 & 4 & $\begin{array}{l}\text { Dehydration, } \\
\text { spherocytosis }\end{array}$ & Lost to follow-up \\
\hline 9 & Male & Black & 39 & 3.12 & Breast & $\begin{array}{l}\downarrow \text { LOC, } \\
\text { opisthotonus, } \\
\text { seizures }\end{array}$ & 742 & 4 & G6PD deficiency & $\begin{array}{l}\text { Athetosis, } \\
\text { epilepsy }\end{array}$ \\
\hline 10 & Male & Black & 37 & 3.06 & Breast & Opisthotonus & 541 & 8 & Dehydration & Normal \\
\hline 11 & Female & White & 41 & 4.3 & Breast & $\downarrow$ LOC, $\downarrow$ tone & 597 & 3 & Rhesus incompatibility & Lost to follow-up \\
\hline 12 & Male & Black & 40 & Unknown & Unknown & $\downarrow L O C, \downarrow$ tone & 699 & 4 & Omphalitis & Died \\
\hline 13 & Male & Black & 37 & 2.73 & Breast & $\begin{array}{l}\downarrow \text { LOC, seizures, } \\
\text { opisthotonus }\end{array}$ & 547 & 5 & $A B O$ incompatibility & $\begin{array}{l}\text { Severe hearing } \\
\text { loss, cerebral } \\
\text { palsy }\end{array}$ \\
\hline 14 & Male & White & 38 & 2.77 & Breast & $\begin{array}{l}\downarrow L O C, \\
\text { opisthotonus }\end{array}$ & 511 & 5 & None identified & $\begin{array}{l}\text { Incidental visual } \\
\text { delay }\end{array}$ \\
\hline
\end{tabular}

$\downarrow$ LOC, impaired consciousness; G6PD, glucose 6-phosphate dehydrogenase; SBR, serum bilirubin.

years, ${ }^{1-4} 68$ there has been little information on current trends in the UK and Ireland. In Wirral, the incidence of moderate hyperbilirubinaemia (total serum bilirubin $\geqslant 340 \mu \mathrm{mol} / \mathrm{l}$ ) increased markedly from $2.4 / 1000$ live births in 1991 to $5.5 /$ 1000 in 2001. ${ }^{12}$ Ours, however, is the first prospective, population-based study of the incidence of severe neonatal jaundice, and bilirubin encephalopathy, in the UK.

Little is known of the incidence of severe neonatal jaundice in other Western countries. Lee et al reported nine infants with a serum bilirubin concentration $\geqslant 510 \mu \mathrm{mol} / \mathrm{l}$ in Ontario between 1992 and 1994, an incidence of 0.38/1000 live births. ${ }^{3}$ Newman et al reported that 0.1/1000 infants born in 1995-6 in a health maintenance organisation catchment area in California had a serum bilirubin concentration $\geqslant 30 \mathrm{mg} / \mathrm{dl}(513 \mu \mathrm{mol} / \mathrm{l}) .{ }^{4}$ In both these studies the total serum bilirubin concentration was used, whereas we used unconjugated serum bilirubin, as we wished to exclude infants with severe liver disease or cholestasis. In infants in the first week of life without such disease, the conjugated serum bilirubin concentration is negligible, ${ }^{9}$ so our findings are comparable with those of Lee et al and Newman et al. The incidence of severe hyperbilirubinaemia cannot be said to be lower in the UK than in North

Table 3 Multivariate logistic analysis of risk factors for encephalopathy, UK and Ireland, 2003-5

\begin{tabular}{|c|c|c|c|}
\hline Variable & Odds ratio & Confidence interval & I V Value \\
\hline Female sex & 0.37 & 0.06 to 2.21 & 0.27 \\
\hline Black/black British & 19.0 & 2.5 to 144.7 & 0.004 \\
\hline Infection & 9.0 & 0.38 to 210.0 & 0.17 \\
\hline $\begin{array}{l}\text { Glucose 6-phosphate } \\
\text { dehydrogenase deficiency }\end{array}$ & 28.2 & 2.6 to 307.7 & 0.006 \\
\hline
\end{tabular}

All odds ratios were mutually adjusted for the other variables in the table.
America, however, because their studies were conducted a decade ago, and the incidence may have fallen following clinical and public health measures taken after the "epidemic" of bilirubin encephalopathy was reported.

There are no national estimates of the incidence of bilirubin encephalopathy for North America, but Ebbesen et al reported eight cases in Denmark between 1994 and 2002, during which time 582600 live term or near-term infants were born: an incidence of 1.4/100 000 live term or near-term births. ${ }^{9}$ This compares with our calculated incidence of 1/100 000 total live births.

The clinical and demographic associations with severe hyperbilirubinaemia that we identified are similar to those reported in North America and Europe. Most infants reported were breast fed. ${ }^{1241314}$ A male preponderance has been described $^{914}$ and near-term infants ${ }^{14781214}$ and infants of ethnic minority origin ${ }^{815}$ have been disproportionately represented. Precise data on the ethnic origin of all live births in Britain and Ireland are not available, but more than half the affected infants in our study were of ethnic minority origin. Finally, the re-emergence of severe neonatal jaundice in North America has coincided with an increasing trend to early discharge of infants from the birth hospital. ${ }^{3}{ }^{13}$

Hyperbilirubinaemia can be aggravated by dehydration due to lactation failure, ${ }^{15689}$ but it can also occur in the presence of successful lactation. ${ }^{15}$ In our study almost all the infants with no associated diagnosis had been breast fed. Infants of ethnic minority origin may be vulnerable for two reasons: first, clinical evaluation of the severity of jaundice may be difficult and second, some ethnic minority groups have a high prevalence of haemolytic diseases such as glucose 6-phosphate dehydrogenase deficiency. Finally, near-term infants may be vulnerable because of relative difficulty in establishing lactation, and relative immaturity of hepatic uptake and conjugation of bilirubin. In addition to dehydration, the other diseases and 


\section{What is already known on this topic}

- In the past 15 years, severe hyperbilirubinaemia and bilirubin encephalopathy have been reported in term and near term infants in the developed world.

\section{What this study adds}

- This is the first prospective, population-based study of severe neonatal hyperbilirubinaemia in the UK and Ireland.

- It provides a robust estimate of the current incidence of severe hyperbilirubinaemia and bilirubin encephalopathy in term and near-term infants.

problems associated with severe hyperbilirubinaemia in our study (haemolysis, infection and marked bruising) have also been identified in North America and Denmark. ${ }^{58} 9$

The infants with bilirubin encephalopathy shared many clinical and demographic features with those who have severe hyperbilirubinaemia without encephalopathy, including male preponderance and ethnic minority origin. An interesting feature of this group was that 3/14 were born at home. Whether these infants received less intensive midwifery surveillance during the first week than infants born in hospital is not known, but presumably they were considered to be at low risk.

A limitation of our study is that the case definition may have excluded infants with bilirubin encephalopathy at serum bilirubin concentrations below our case definition. Of 125 infants reported to the Philadelphia kernicterus registry, 19 had bilirubin encephalopathy at bilirubin concentrations below $30 \mathrm{mg} / \mathrm{dl}(513 \mu \mathrm{mol} / \mathrm{l}){ }^{8}{ }^{8}$ Possibly our study failed to identify comparable infants in the UK and Ireland. Our case definition may also have excluded some infants with encephalopathy associated with severe conjugated hyperbilirubinaemia. ${ }^{16}$ Also, because the focus of our study was primarily epidemiological and could not collect comprehensive clinical information on individual infants, we may have under-identified mild bilirubin encephalopathy. The calculated incidence of bilirubin encephalopathy should be regarded, therefore, as a minimum.

The strengths of our study include its prospective design, and the comprehensive national coverage of paediatric and maternity units in Britain. Almost all consultant paediatricians in the UK are members of the Royal College of Paediatrics and Child Health and therefore receive a monthly mailing from the British Paediatric Surveillance Unit. The mean response rate to this is $92 \%,{ }^{17}$ and for many cases we received duplicate reports from colleagues. Under-ascertainment, therefore, is likely to be minimal.

It is of concern that 59 infants with severe hyperbilirubinaemia did not undergo exchange transfusion. This group of infants had lower median serum bilirubin concentrations, and less frequent associated haemolysis, than infants receiving exchange transfusion. Our study was not designed to examine treatment decisions, but we speculate that in some cases intensive phototherapy and rehydration resulted in rapid reduction in serum bilirubin and deferral of exchange transfusion. Neurological symptoms, such as impaired conscious level and hypotonia, may in some infants have been attributed to associated morbidity such as infection and dehydration.
Arguably, however, such symptoms in the presence of severe hyperbilirubinaemia warrant urgent exchange transfusion.

Our findings have important implications. We have shown that severe hyperbilirubinaemia and bilirubin encephalopathy, which have been reported with increasing frequency in North America and Europe, have also occurred in the UK and Ireland. We have also shown that the same clinical, pathological and demographic associations are relevant here. These findings are important, not just for paediatricians and neonatologists, but also for midwives, general practitioners, public health professionals and commissioners of primary care services. The "kinder, gentler" approach to the investigation and management of neonatal jaundice which was advocated in the 1980s and 1990s should be re-evaluated. ${ }^{18}$ Unfortunately, clinical practice in surveillance and treatment of neonatal jaundice varies widely, ${ }^{19}$ probably because many aspects of such management are not supported by a firm evidence base. ${ }^{20}$

Nonetheless, some cases of severe hyperbilirubinaemia and bilirubin encephalopathy may be preventable. Severe jaundice often presents after the infant has been discharged from the birth hospital, and sometimes after home delivery. Careful community-based surveillance of all infants who are discharged early, supplemented by laboratory measurement of serum bilirubin and other investigations as appropriate, is essential. Particular vigilance is required for near-term infants and infants of ethnic minority origin, and clinical assessment should include assessing the adequacy of lactation. As severe jaundice also presented in hospital in 20 cases, the same principles apply to infants cared for on postnatal wards. Finally, parents of newborn infants should be given comprehensive information about neonatal jaundice and the possible consequences (albeit uncommon) of delay in establishing successful breast feeding.

\section{ACKNOWLEDGEMENTS}

We gratefully acknowledge the support of the British Paediatric Surveillance Unit, and the Clinical Practice Research Unit, Wirral Hospital.

\section{Authors' affiliations \\ Donal Manning, Peter Todd, Department of Paediatrics, Arrowe Park Hospital, Wirral, Merseyside, UK \\ Melanie Maxwell, Clinical Practice Research Unit, Arrowe Park Hospital, Wirral, Merseyside, UK \\ Mary Jane Platt, Division of Public Health, University of Liverpool, Liverpool, UK}

This study was funded by Wirral Hospital NHS Trust and Wirral Hospital Neonatal Unit Endowment Fund. The funders had no involvement in study design, in collection, analysis or interpretation of the data, in the writing of the paper, or in the decision to submit the paper for publication.

Competing interests: None.

\section{REFERENCES}

1 Maisels MJ, Newman TB. Kernicterus in otherwise healthy, breast-fed term newborns. Pediatrics 1995;96:730-3.

2 Seidman DS, Stevenson DK, Ergaz Z, et al. Hospital readmission due to neonatal hyperbilirubinaemia. Pediatrics 1995;96:727-9.

3 Lee K-S, Perlman M, Ballantyne M, et al. Association between duration of neonatal hospital stay and readmission rate. J Pediatr 1995; 127:758-66.

4 Newman TB, Escobar GJ, Gonzales VM, et al. Frequency of neonatal bilirubin testing and hyperbilirubinaemia in a large health maintenance organisation. Pediatrics 1999; 104:1 198-203.

5 Ebbesen F. Recurrence of kernicterus in term and near-term infants in Denmark. Acta Paediatr 2000;89:1213-7.

6 Johnson LH, Bhutani VK, Brown AK. System-based approach to management of neonatal jaundice and prevention of kernicterus. J Pediatr 2002; 140:396-403.

7 Sarici SU, Serdar MA, Korkmaz A, et al. Incidence, course, and prediction of hyperbilirubinaemia in near-term and term newborns. Pediatrics 2004;113:775-80. 
8 Bhutani VK, Johnson LH, Maisels MJ, et al. Kernicterus: epidemiological strategies for its prevention through systems-based approaches. J Perinatol 2004;24:650-62.

9 Ebbesen $\mathrm{F}$, Andersson $\mathrm{C}$, Verder $\mathrm{H}$, et al. Extreme hyperbilirubinaemia in term and near-term infants in Denmark. Acta Paediatr 2005:94:59-64.

10 Connolly AM, Volpe JJ. Clinical features of bilirubin encephalopathy. Clin Perinatol 1990;17:371-9.

11 Yilmaz Y, Alper G, Kilicoglu G, et al. Magnetic resonance imaging findings in patients with severe neonatal indirect hyperbilirubinaemia. J Child Neurol $2001 ; 16: 452-5$.

12 Walston F, Manning D, Neithercut WD. Increasing incidence of moderate neonatal hyperbilirubinaemia in Wirral. Arch Dis Child Fetal Neonatal Ed 2004;89:F374.

13 Maisels MJ, Kring E. Length of stay, jaundice, and hospital readmission. Pediatrics 1998; 101:995-8.
14 Newman TB, Liljestrand P, Escobar GJ. Infants with bilirubin levels of $30 \mathrm{mg} / \mathrm{dL}$ or more in a large managed care organisation. Pediatrics 2003:111:1303-11.

15 Maisels MJ, Gifford K. Normal serum bilirubin levels in the newborn and the effect of breast-feeding. Pediatrics 1986;78:837-43.

16 Bertini G, Dani C, Fonda C, et al. Bronze baby syndrome and the risk of kernicterus. Acta Paediatr 2005:94:968-71.

17 British Paediatric Surveillance Unit. BPSU 19th annual report 2004-2005. London: British Paediatric Surveillance Unit, 2005.

18 Ives NK. Neonatal jaundice. In: Rennie JM, eds. Roberton's textbook of neonatology, 4th edn. Elsevier: Churchill Livingstone, 2005:661-78.

19 Skae MS, Moise J, Clarke P. Is current management of neonatal jaundice evidence based? Arch Dis Child Fetal Neonatal Ed 2005:90:F540.

20 American Academy of Pediatrics. Management of hyperbilirubinaemia in the newborn infant 35 or more weeks of gestation. Pediatrics 2004;1 14:297-316.

\section{BMJ Clinical Evidence-Call for contributors}

BMJ Clinical Evidence is a continuously updated evidence-based journal available worldwide on the internet which publishes commissioned systematic reviews. BMJ Clinical Evidence needs to recruit new contributors. Contributors are healthcare professionals or epidemiologists with experience in evidence-based medicine, with the ability to write in a concise and structured way and relevant clinical expertise.

Areas for which we are currently seeking contributors:

- Secondary prevention of ischaemic cardiac events

- Acute myocardial infarction

- MRSA (treatment)

- Bacterial conjunctivitis

However, we are always looking for contributors, so do not let this list discourage you.

\section{Being a contributor involves:}

- Selecting from a validated, screened search (performed by in-house Information Specialists) valid studies for inclusion.

- Documenting your decisions about which studies to include on an inclusion and exclusion form, which we will publish.

- Writing the text to a highly structured template (about 1500-3000 words), using evidence from the final studies chosen, within 8-10 weeks of receiving the literature search.

- Working with BMJ Clinical Evidence editors to ensure that the final text meets quality and style standards.

- Updating the text every 12 months using any new, sound evidence that becomes available. The BMJ Clinical Evidence in-house team will conduct the searches for contributors; your task is to filter out high quality studies and incorporate them into the existing text.

- To expand the review to include a new question about once every 12 months.

In return, contributors will see their work published in a highly-rewarded peer-reviewed international medical journal. They also receive a small honorarium for their efforts.

If you would like to become a contributor for BMJ Clinical Evidence or require more information about what this involves please send your contact details and a copy of your CV, clearly stating the clinical area you are interested in, to CECommissioning@bmigroup.com.

\section{Call for peer reviewers}

BMJ Clinical Evidence also needs to recruit new peer reviewers specifically with an interest in the clinical areas stated above, and also others related to general practice. Peer reviewers are healthcare professionals or epidemiologists with experience in evidence-based medicine. As a peer reviewer you would be asked for your views on the clinical relevance, validity and accessibility of specific reviews within the journal, and their usefulness to the intended audience (international generalists and healthcare professionals, possibly with limited statistical knowledge). Reviews are usually $1500-3000$ words in length and we would ask you to review between 2-5 systematic reviews per year. The peer review process takes place throughout the year, and our turnaround time for each review is 10-14 days. In return peer reviewers receive free access to BMJ Clinical Evidence for 3 months for each review.

If you are interested in becoming a peer reviewer for BMJ Clinical Evidence, please complete the peer review questionnaire at www.clinicalevidence.com/ceweb/contribute/peerreviewer.jsp 